\title{
Dose Rate Reduced
}

National Cancer Institute

\section{Source}

National Cancer Institute. Dose Rate Reduced. NCI Thesaurus. Code C150826.

An indication that the administration of a medication was modified by reducing the rate at which the dose was given. 